\title{
DIVIDED, BUT NOT BY MUCH: THE PARTIES OF THE CENTRE RIGHT BETWEEN GOVERNMENT AND OPPOSITION
}

\author{
Elisabetta De Giorgi (Università di Trieste) and António Dias (ICS-UL)
}

For the parties of the centre right, 2019 provided confirmation, at both the local and regional levels, that their alliance was solid. Although it is based entirely on strategic needs, it continues to bear fruit despite the fact that its internal distribution of power has completely changed. The year began and ended with a series of significant victories both in local elections - where the centre right managed to wrest a number of important provincial capitals from the centre left - and in regional elections - with triumphal victories in Abruzzo and Sardinia in February, and in Umbria in October, not to mention Basilicata and Piemonte in the spring. The distribution of power within the coalition, however, has changed radically. The Lega (League) has become the new dominant force within the coalition at national level and, in many cases, at regional level also. Fratelli d'Italia (Brothers of Italy, FdI) is growing strongly. Forza Italia (FI) is declining ever more rapidly. In Parliament, changes were decidedly more complex. At the beginning of the year, the three parties were divided between the government and the opposition. The League, together with the Movimento Cinque Stelle (Five-star Movement, M5s), formed part of the majority supporting the yellow-green government; FI and Fdl were part of the minority. However, at the end of the year, the old allies found themselves once again united in opposition to the new government formed by the Partito Democratico (Democratic Party, PD) and the M5s.

In this article we shall re-examine the events that distinguished the year in question in order to understand to what extent and how the centre-right coalition changed over time. We shall also consider how the three parties reacted to the new political circumstances which, until the end of the summer, meant that they were governing allies at the municipal and regional levels and on opposing sides at the national level.

Electorally, the distribution of power, as we have said, has changed considerably, and has changed in all arenas, local and regional, national and European. One should not forget, for example, that 2019 was the year of the European Parliament elections, which saw Matteo Salvini's League exceed $30 \%$ of the vote and thus become the largest party in Italy. At the municipal and regional levels, the alliance remained intact, since the parties held fast to their strategic outlook according to which victory for each of them was dependent on the unity of all of them. At the national level, in contrast, until August, the three allies had very different positions, the League being in government, and $\mathrm{Fl}$ and 
Fdl in opposition. What kind of opposition did these two parties engage in, in their interaction with the yellow-green government? Given their collaboration at the municipal and regional levels; given that they had previously been allies and the national level, and given their proximity on the left-right spectrum, the question arises: did the three parliamentary party groups adjust to their new role and the new division between them, or did they in some way continue to collaborate in Parliament?

These are the questions we shall seek to answer in the remainder of this article. The data on which we base our analysis have been drawn from two main sources: the Chamber of Deputies' data base concerning legislative initiatives; ${ }^{1}$ the Ministry of the Interior's data concerning regional elections, and regional executives and councils. ${ }^{2}$ The article is divided into three sections. The first focuses on the main political initiatives undertaken by the parties of the centre right in the period leading up to 2019. The second considers their alliance - especially at regional level - and their respective electoral successes during the year we are considering. The final section analyses their interaction in the parliamentary arena during the period of office of the first Conte government.

\section{The centre right between government and opposition}

Through a whole series of ups and downs, the alliance between the Lega Nord (Northern League) and $\mathrm{FI}$ - subsequently the Popolo della Libertà (People of Freedom, PdL) - remained intact for more than a decade until the end of 2011. Then, with the resignation of the fourth Berlusconi government and the appointment of the Monti government in its place, the paths of the two parties officially diverged. They had never drawn so close as to merge or even to subscribe to a joint election manifesto. However, before 2011, the alliance had never officially been broken even when the parties had been in opposition. Depending on political circumstances they had either been cohesively in government, or in opposition. With the advent of the Monti government, the League and the PdL for the first time made the opposite choices. The League stuck to its firm opposition to the new executive, while for most of the time the PdL participated in the grand coalition whose external support maintained the government in office.

According to a number of observers, problems between the parties had already begun to emerge during the fourth Berlusconi government's term. The relationship that had been established between the Prime Minister and Umberto Bossi - a relationship which many considered to be highly unequal - had often given the impression that the Northern League leader was holding the government to ransom - both for reasons of policy and for political reasons more broadly (Albertazzi

\footnotetext{
${ }^{1}$ Available at www.dati.camera.it

${ }^{2}$ https://elezionistorico.interno.gov.it/
} 
and McDonnell, 2010; De Giorgi, 2010). Despite this, a survey of the members of both parties suggested that though PdL members saw the League's stances and political style as being sometimes too intransigent, they nevertheless respected their ally, its effective style of communication and its rootedness in local communities (Albertazzi, 2013). For their part, members of the Northern League were extremely critical of the PdL and Berlusconi, and many of them, while accepting the alliance, saw it as a 'marriage of convenience'.

The League, aware of these attitudes, had always sought to play an ambivalent role within the coalition, acting as a sort of internal opposition from within the government, but at the same time endeavouring to exploit the position of power which the alliance gave it. In other words, at the national level it had always tried, with not inconsiderable success, to have 'one foot inside and one foot outside' the executives of which it had been a part (Albertazzi and McDonnell, 2005).

Moreover, once the Monti government had left office, the parties had been able to stitch their alliance together again - both at the national level (De Giorgi and Tronconi, 2018), and at the local and regional levels (Tronconi, 2015; Emanuele and Maggini, 2017; Emanuele and Paparo, 2017). Important in this was their ideological proximity, their ability to understand each other's priorities and, above all, their awareness of their shared strategic interest in presenting a united front in elections at all levels of government.

The current electoral system at the national level, which came into force at the end of 2017, provides for about one third of the parliamentary seats to be distributed according to the singlemember, simple plurality formula - while the system used for the regions provides for the direct election of regional presidents, conjointly with regional councils. ${ }^{3}$ It has therefore always been essential, from a strategic point of view, to put aside differences and to line up behind common candidates.

The tactics adopted by the League in the aftermath of the parliamentary elections of 2018 were, naturally, different. Then, exploiting the numbers it had, and the political space that had been opened up for it by the M5s, it had no hesitation in abandoning its old allies and embarking on the new path laid out for it with the formation of the yellow-green government (Chiaramonte et al., 2018). This novel step was taken only after the League, now under the leadership of Salvini, had initiated a process of redefinition of the party's identity. This involved side-lining the emphasis on the independence of Padania and the attacks on an unproductive South (Cento Bull and Gilbert, 2001; Biorcio and Vitale, 2014; Huysseune, 2015) with the aim of attracting support throughout the country - this by positioning the party on the extreme, anti-immigrant, anti-Euro, right (Passarelli, 2013; Vampa, 2017).

\footnotetext{
${ }^{3} \mathrm{~A}$ similar system, which favours large parties, or in their absence, coalitions, is also used for the election of mayors and municipal councils.
} 
This enabled it to win support in the central and southern regions where, until a few years previously, its support had been thin, to say the least. In the meantime, the newly reconstituted FI, together with its leader, lost appeal and support - while Giorgia Meloni's Fdl continued to attract the 'nostalgic' voters who had previously supported the Movimento Sociale Italiano (Italian Social Movement, MSI), and began to attract the new 'sovereignists' closer to the neo-fascist right.

In short, the distribution of power within the centre right had already begun to shift before 2019, but the European elections without doubt constituted a new watershed. In the aftermath of the parliamentary elections of 2018, Berlusconi could still lay claim to significant role for himself and his party, if only by exploiting the political capital arising from the fact that he had been the founder of the coalition. This is, in effect, precisely what he did - until the League decided upon an independent course by inaugurating the unprecedented yellow-green coalition. A memorable event was the scene broadcast, live, following the consultations with the head of state. Then, the centre right's joint declaration was read by Salvini, but Berlusconi made a point of demonstrating that he knew almost all of the declaration by heart, mouthing Salvini's words, and counting the programmatic points on the fingers of his right hand. And following the ritual concluding remarks, he literally pushed Salvini and Meloni away from the lectern, grabbing the microphone to speak to the assembled journalists, and openly attacking a Five-star Movement with which the League was already said to be involved in preliminary negotiations.

After the elections in Abruzzo, Sardinia and Basilicata (between February and March 2019), but especially after the elections for the European Parliament in May, the situation changed decisively. Surprise gave way to the recognition and the (near) acceptance that Salvini was, if not the leader of the coalition - a shared desire for permanent coordination among the three parties was clearly lacking - at least the leader with the highest media profile. Winning $34.4 \%$ of the vote in the European elections, the League became the largest party in Italy, north and south. At the parliamentary elections it had won an already surprising $17.4 \%$, having taken just $6.2 \%$ at the preceding European elections in 2014. In short, it reached an historic high point. FI meanwhile continued to decline. Managing just $8.8 \%$ (having won $14 \%$ at the parliamentary elections), it was well short of the psychologically significant $10 \%$ threshold which might have shielded it from internal tensions and possible desertions and breakaways. A very positive result, lastly, was obtained by $\mathrm{Fdl}$, which took $6.5 \%$. With the European elections, the balance of power within the (former) centre-right coalition shifted decisively. 
The alliance at regional level: 2019, the year of eclipses

At the end of 2019, the centre right, as Figure 1 shows, controlled 11 regional councils as compared to 7 controlled by the centre left (excluding the autonomous provinces of Trento and Bolzano - which, however, were administered by an alternative centre-right coalition - and the Valle d'Aosta, controlled by regional autonomy parties). Recent elections have seen a seismic shift of votes from the left to the right - not only at regional, but also at the local-council level. The Italian municipal elections of 2019 were, for the most part, held at the end on May on the same day as the European contest, and they resulted in the election of new mayors in 28 provincial capitals. In Sicily, they were instead held at the end of April, and in Sardinia on 16 June. The final result was an overall tie between centre left and centre right in terms of numbers of victories, but what should be noted is that more than half the municipalities won by the centre right had previously been in the hands of the centre left. Therefore, the League-FI-Fdl coalition was, at the local level, the undisputed winner of the year's elections.

The same can be said about the regional elections. Here, the centre right overtook the centre left at the beginning of 2019, the March elections in Basilicata seeing the triumph of Vito Bardi - while the centre right had drawn level with the centre left just a month earlier, in February, with the victory of Christian Solinas in Sardinia. Between 2018 and 2019, a further five regions had passed from the centre left to the centre right: Molise, Friuli Venezia Giulia, the two autonomous provinces of Trento and Bolzano, and Abruzzo. 
FIGURE 1 Regions governed by the centre right

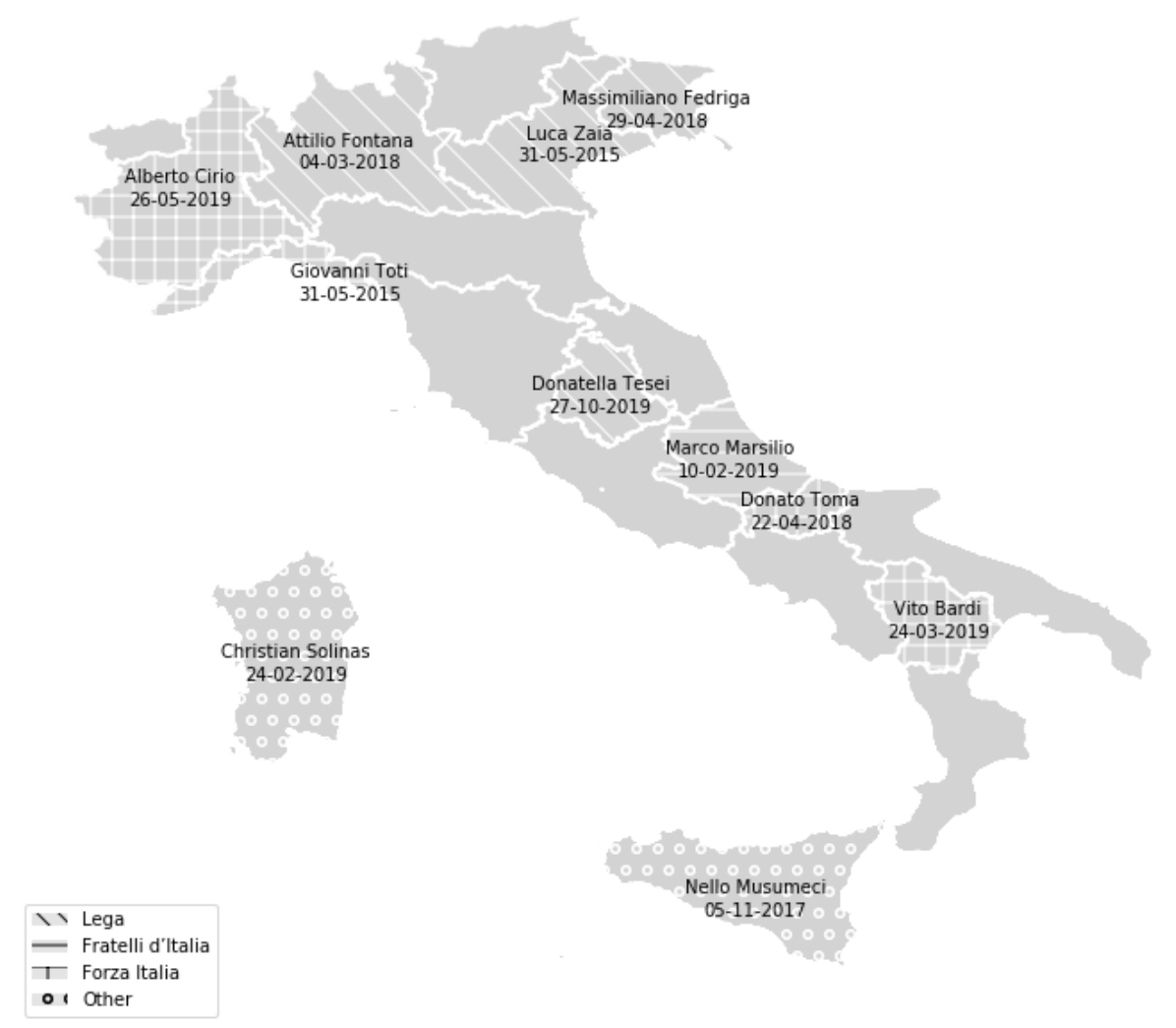

The year began with the elections, early in February, in Abruzzo, where the centre right conquered a region which, for the previous five years, had been governed by an executive staffed by the PD and led by Luciano D'Alfonso (subsequently elected as a senator in the parliamentary elections of 2018). The elections in Abruzzo represented an important milestone for the centre right. This was not only because it was victorious, but also because Marco Marsilio, the winning candidate, was a representative of Fdl and the because the League, in an area that was not one of its own, so to speak, took $27.5 \%$ of the vote, thus confirming its undisputed leadership of the alliance (Table 1). FI, on the other hand, retreated still further, winning $9 \%$ of the vote, which was five percentage points down on its performance at the 2018 parliamentary elections and seven percentage points down on its performance at the 2014 European elections in Abruzzo. 
The result of the regional elections in Sardinia, a few weeks later, confirmed the trends already apparent from the elections in Abruzzo, but with some significant differences. Christian Solinas, of the Partito Sardo d'Azione (Sardinian Action Party, PSdA), supported by the parties of the centre right, became the new president of the Sardinian region, winning $47.8 \%$ of the votes. But if the outcome of the elections in Abruzzo had enabled the League to feel ecstatic, giving it a position as by far the largest party, in Sardinia, the most-voted party (even if marginally) was the PD (with 13.4\%). It was followed by the League (11.4\%), the PSdA (which, as the party providing the coalition's regional presidential candidate, took 9.9\%), the M5s, FI (8\%), Riformatori sardi (5\%), Fdl (4.7\%) and other parties. In other words, the gap between the two main centre-right parties was much smaller in this contest, and this circumstance enabled Berlusconi to declare that 'Salvini without Forza Italia [was] not self-sufficient' . This was a leit motiv which, in the period following the elections, was repeated, in more or less the same terms, by all the spokespersons for Berlusconi's party.

However, March 2019, as we have said, saw the centre right overtake the centre left. Thus, in Basilicata, a region that had until then been governed by the centre left, Vito Bardi, the centre right's candidate, won $42.2 \%$ (Table 1 ), outdistancing his main rival by ten percentage points. The performances of the individual political parties were even more striking. Thus, as compared to its performance at the parliamentary elections of 2018, the League increased its support in the region by a factor of three (going from $6.2 \%$ to $19 \%$ ). Salvini therefore had to hand all the figures he needed to enable him to claim to be the 'moral victor' of these elections. $\mathrm{Fl}$, in fact, once more lost ground (as compared to the outcome, in the region, of the 2018 elections) and fell to $9 \%$ - while Fdl grew, reaching around $6 \%$.

\footnotetext{
4 II Fatto Quotidiano, 25 February 2019, Elezioni Sardegna, il centrodestra vince: Solinas al 47\%, Zedda (centrosinistra) al 33\%. Crolla il M5s: è all'11\%: https://www.ilfattoquotidiano.it/2019/02/25/elezioni-sardegnail-centrodestra-vince-solinas-al-47-zedda-centrosinistra-al-33-crolla-il-m5s-all11-ora-per-ora/4995096/
} 
TABLE 1 Regions administered by the centre right, and corresponding election results

\begin{tabular}{|c|c|c|c|c|c|c|c|c|c|c|c|}
\hline \multirow[b]{2}{*}{ Region } & \multirow[b]{2}{*}{ Elezions } & \multicolumn{2}{|c|}{ President } & \multicolumn{2}{|c|}{ Coalition } & \multicolumn{2}{|c|}{ FI } & \multicolumn{2}{|c|}{ League } & \multicolumn{2}{|c|}{ Fdl } \\
\hline & & Name & Party/list & $\begin{array}{c}\text { Votes } \\
(\%)\end{array}$ & $\begin{array}{c}\text { Seats } \\
(\%) \\
\end{array}$ & $\begin{array}{c}\text { Votes } \\
(\%) \\
\end{array}$ & $\begin{array}{c}\text { Seats } \\
(\%)\end{array}$ & $\begin{array}{c}\text { Votes } \\
(\%) \\
\end{array}$ & $\begin{array}{c}\text { Seats } \\
(\%)\end{array}$ & $\begin{array}{c}\text { Votes } \\
(\%) \\
\end{array}$ & $\begin{array}{c}\text { Seats } \\
(\%)\end{array}$ \\
\hline Liguria & $31 / 05 / 2015$ & $\begin{array}{l}\text { Giovanni } \\
\text { Toti }\end{array}$ & Forza Italia & $34.44 \%$ & $51.61 \%$ & $12.66 \%$ & $9.68 \%$ & $20.25 \%$ & $16.13 \%$ & $3.07 \%$ & $3.23 \%$ \\
\hline Veneto & $31 / 05 / 2015$ & Luca Zaia & Lega & $50.08 \%$ & $57.14 \%$ & $5.97 \%$ & $6.12 \%$ & $17.82 \%$ & $20.41 \%$ & $2.60 \%$ & $2.04 \%$ \\
\hline Sicilia & $05 / 11 / 2017$ & $\begin{array}{c}\text { Nello } \\
\text { Musumeci }\end{array}$ & $\begin{array}{l}\text { Diventerà } \\
\text { Bellissima }\end{array}$ & $39.85 \%$ & $51.43 \%$ & $16.37 \%$ & $17.14 \%$ & $5.65 \%$ & $4.29 \%$ & & \\
\hline Lombardia & 04/03/2018 & $\begin{array}{l}\text { Attilio } \\
\text { Fontana }\end{array}$ & Lega & $49.75 \%$ & $61.54 \%$ & $14.34 \%$ & $17.95 \%$ & $29.68 \%$ & $35.90 \%$ & $3.64 \%$ & $3.85 \%$ \\
\hline Molise & $22 / 04 / 2018$ & $\begin{array}{l}\text { Donato } \\
\text { Toma }\end{array}$ & Forza Italia & $43.69 \%$ & $63.16 \%$ & $9.38 \%$ & $15.79 \%$ & $8.23 \%$ & $10.53 \%$ & $4.45 \%$ & $5.26 \%$ \\
\hline $\begin{array}{c}\text { Friuli-Venezia } \\
\text { Giulia }\end{array}$ & $29 / 04 / 2018$ & $\begin{array}{l}\text { Massimiliano } \\
\text { Fedriga }\end{array}$ & Lega & $57.09 \%$ & $59.57 \%$ & $12.06 \%$ & $10.64 \%$ & $34.91 \%$ & $36.17 \%$ & $5.49 \%$ & $4.26 \%$ \\
\hline Abruzzo & $10 / 02 / 2019$ & $\begin{array}{l}\text { Marco } \\
\text { Marsilio }\end{array}$ & Fratelli d'Italia & $48.03 \%$ & $58.62 \%$ & $9.04 \%$ & $10.34 \%$ & $27.53 \%$ & $34.48 \%$ & $6.48 \%$ & $6.90 \%$ \\
\hline Sardegna & $24 / 02 / 2019$ & $\begin{array}{l}\text { Christian } \\
\text { Solinas }\end{array}$ & $\begin{array}{l}\text { Partito Sardo } \\
\text { d'Azione }\end{array}$ & $47.78 \%$ & $60.00 \%$ & $8.04 \%$ & $8.33 \%$ & $11.40 \%$ & $13.33 \%$ & $4.72 \%$ & $5.00 \%$ \\
\hline Basilicata & $24 / 03 / 2019$ & Vito Bardi & Forza Italia & $42.20 \%$ & $63.16 \%$ & $9.14 \%$ & $15.79 \%$ & $19.15 \%$ & $31.58 \%$ & $5.91 \%$ & $5.26 \%$ \\
\hline Piemonte & $26 / 05 / 2019$ & Alberto Cirio & Forza Italia & $48.86 \%$ & $64.71 \%$ & $8.39 \%$ & $5.88 \%$ & $37.11 \%$ & $33.33 \%$ & $5.49 \%$ & $3.92 \%$ \\
\hline Umbria & $27 / 10 / 2019$ & $\begin{array}{l}\text { Donatella } \\
\text { Tesei }\end{array}$ & Lega & $57.55 \%$ & $57.14 \%$ & $5.50 \%$ & $4.76 \%$ & $36.95 \%$ & $38.10 \%$ & $10.40 \%$ & $9.52 \%$ \\
\hline
\end{tabular}


The three leaders of the centre-right coalition appeared with decreasing frequency together in public, and, as several newspapers noted, they even celebrated the regional election outcomes, favourable as they were, separately. Despite everything, however, they continued to believe it advantageous to present common candidates at regional elections, and so they did in Piemonte and Umbria in the following months. The elections in Piemonte, in May, were significant, because the centre right defeated the outgoing regional president, Sergio Chiamparino, former mayor of Turin and high-profile spokesperson for the PD, outdistancing him by about 13 percentage points. In so doing, they wrested from the centre left control of its last remaining region in the North.

The last region to hold elections in 2019 was Umbria. The outcome was significant in several respects. In the first place, it meant that the League had reached parity with FI in terms of the number of regions presided over by one of its own, ${ }^{5}$ but it also opened the way for the League to take control of a region located outside of its 'comfort zone', namely, northern Italy. Finally, the outcome was based on a very high turnout. As the Istituto Cattaneo pointed out, not only did the turnout buck the trend of the last three decades, but it was the highest ever recorded for a regional election in Umbria. ${ }^{6}$ This indicated that Umbrian voters had considered the election to be very important - and a large majority of them voted for change: the region had, in fact, historically been governed by the centre left. Among the parties of the centre right, the most significant result was for Salvini's League which, in absolute terms, increased its support by three times as compared to the previous elections and took $37 \%$ of the vote. Significant growth was also achieved by Fdl, which doubled its support both in absolute and percentage terms and took $10 \%$. As had already happened at the elections in other regions, $\mathrm{Fl}$ suffered considerable losses - which in this case were made even more significant by the fact that, in retreating to $5.5 \%$, it was also overtaken by Giorgia Meloni's party, which was able to celebrate an historic second place.

The shift in the balance of power within the coalition was now an accomplished fact, with a considerable reinforcement of the League and Fdl, and the progressive weakening of Fl. In 2019, the so-called 'sovereignist' pole showed that it was on a clear upward trajectory in electoral terms. Whether this would result in the moderate wing represented by FI progressively distancing itself from the coalition, or in its final collapse, remained to be seen.

\footnotetext{
${ }^{5}$ The calculation once again excludes the autonomous provinces of Trento and Bolzano.

${ }^{6}$ The complete analysis can be found at:: http://www.cattaneo.org/wp-content/uploads/2019/10/AnalisiIstituto-Cattaneo-Regionali-Umbria-2019-Chi-ha-vinto_chi-ha-perso-1.pdf
} 


\section{The centre right in Parliament: were we once much in love - or have we never left each other?}

As mentioned in the introduction, if at the regional level the centre-right coalition remained, for strategic reasons, united in 2019 , then in Parliament, matters were considerably more complex. From May 2018 until the summer of 2019, in fact, the forces of the centre right had to come to terms with what was for them a completely unprecedented set of circumstances, with the League forming part of the government and Fl and Fdl taking their places among the ranks of the opposition. What we seek to understand in this section is the kind of opposition strategy these two parties sought to advance with respect to the yellow-green government and, consequently, their (former) ally. Did the parliamentary groups seek to adjust to the change of roles by advancing a strategy of intransigent opposition? Or did they, in some way, shape or form, continue to collaborate, given that their alliance was still in being at the regional and local levels and had been in being at the national level until very recently?

We attempt to answer these questions by analysing two types of activity on the part of the parties' followers in Parliament. We look, first, at co-sponsorship of legislative initiatives. In other words, we consider the number of times a parliamentarian representing a given party (in this case one of the three parties of the centre right) chose to sign, and thus to support, a bill presented by a parliamentarian belonging to one of the other groups (in this case, one of the other two centre-right groups). We look, second, at how they voted at the final reading of bills sponsored by the government. In this way we will be able to see whether the earlier collaboration between the allies (measured in terms of the extent to which bills sponsored by one of them were also sponsored by the others) declined or remained unchanged. On the other hand, we will be able to establish whether the level of conflict, measured in terms of voting against government bills, was similar to that for previous governments - when all three parties were in opposition - or whether, with a former ally in government, it went down. In other words, we will see whether the fact of having had a long history of collaboration in government, and having still functioning alliances at regional and local levels, did or did not affect the behaviour of Fl, Fdl and the League in Parliament.

We have identified, collected and analysed, two types of data. In the first place, we have considered all the bills presented to the Chamber of Deputies from February 2014 following the formation of the Renzi government. More precisely, we have gathered information concerning the principal and the other signatories of these bills (not all of which were passed, obviously). We have done this in order to discover whether it is possible to distinguish different types of cooperation by considering which, among the centre-right parties, provided the principal signatory and whether they were part of the government or the opposition. In other words, what we are particularly interested in 
discovering is whether cooperation between the three parties of the centre right came to a halt after the League joined the first Conte government, leaving its old partners behind among the ranks of the opposition.

In addition, we have gathered information, starting from the same date, concerning the votes cast by members of Parliament with respect to government bills. For each parliamentary group, we created an index of opposition, given by the relationship between the negative votes expressed by each group and the total number of parliamentarians belonging to the group (thereby including both those actually present for the vote - who could thus have voted for or against or abstained - and those who were absent). We then calculated the simple average, per group, per government. The objective, obviously, is to establish whether the level of opposition to government bills, among the parties of the centre right, was larger than, smaller than or the same as, the level of opposition on display after the League joined the new governing majority.

TABLE 2 Co-sponsorship: percentage of bills signed by other parties of the centre right (and absolute numbers)

\begin{tabular}{lccccccccc}
$\begin{array}{l}\text { Primary/other } \\
\text { signatories }\end{array}$ & \multicolumn{3}{c}{ Renzi } & \multicolumn{4}{c}{ Gentiloni } & \multicolumn{3}{c}{$\begin{array}{c}\text { Conte I } \\
\text { (2018-19) }\end{array}$} \\
\cline { 2 - 11 } & FI & Fdl & Lega & FI & Fdl & Lega & FI & Fdl & Lega \\
\hline \multirow{4}{*}{ FI } & $33.0 \%$ & $8.1 \%$ & $3.2 \%$ & $24.0 \%$ & $4.0 \%$ & $2.0 \%$ & $41.2 \%$ & $3.4 \%$ & $2.1 \%$ \\
& $(61)$ & $(15)$ & $(6)$ & $(12)$ & $(2)$ & $(1)$ & $(156)$ & $(13)$ & $(8)$ \\
FdI & $5.3 \%$ & $26.7 \%$ & $1.3 \%$ & $8.3 \%$ & $62.5 \%$ & $4.2 \%$ & $9.2 \%$ & $71.8 \%$ & $1.8 \%$ \\
& $(4)$ & $(20)$ & $(1)$ & $(2)$ & $(15)$ & $(1)$ & $(15)$ & $(117)$ & $(3)$ \\
Lega & $1.4 \%$ & $0.0 \%$ & $83.6 \%$ & $0.0 \%$ & $0.0 \%$ & $100.0 \%$ & $1.7 \%$ & $2.3 \%$ & $100.00 \%$ \\
& $(1)$ & $(0)$ & $(61)$ & $(0)$ & $(0)$ & $(42)$ & $(3)$ & $(4)$ & $(176)$
\end{tabular}

Table 2 shows the results of the first analysis, the analysis concerning collaboration among the parties of the centre right in respect of legislative proposals. We begin with the bills presented by members of the League's parliamentary group with co-signatories drawn from Fl and Fdl. During the Renzi and Gentiloni governments, with one exception the two parties never collaborated with the League in presenting bills. On the other hand, during the first Conte government, when the two parties were formally opposed to the League (and the M5s) the number increases slightly. Both in absolute and percentage terms, the number of bills is small, but what we are interested in showing is that collaboration among the three parties, far from ceasing, if anything grew slightly. The same conclusion is reached when we consider the bills whose principal signatories were members of FI and Fdl. The League, especially in the case of $\mathrm{Fl}$, had co-signed a number of bills during both the Renzi and the Gentiloni governments, and the same thing happened during the first Conte government when members of Salvini's party co-signed eight bills presented by $\mathrm{FI}$ (about $2 \%$ of the bills presented by FI 
in that period) and three presented by Fdl. The figure does not seem particularly significant in view of the rather small numbers, but it serves to demonstrate that the attitudes of and the relationships between the three parties in Parliament did not significantly change.

We come now to the index of opposition, which, as we have said, measures in a rather intuitive way, the level of opposition to the government's legislative initiatives. Not surprisingly, the League, having switched from opposition to government, has an opposition index score of zero (Figure 2). Besides this, the most interesting result is given by the notable reduction in the average score for $\mathrm{FI}$ and Fdl as we pass from the Renzi and Gentiloni governments, on the one hand, to the first Conte government on the other.

FIGURE 2 Index of opposition of the parties of the centre right, by government

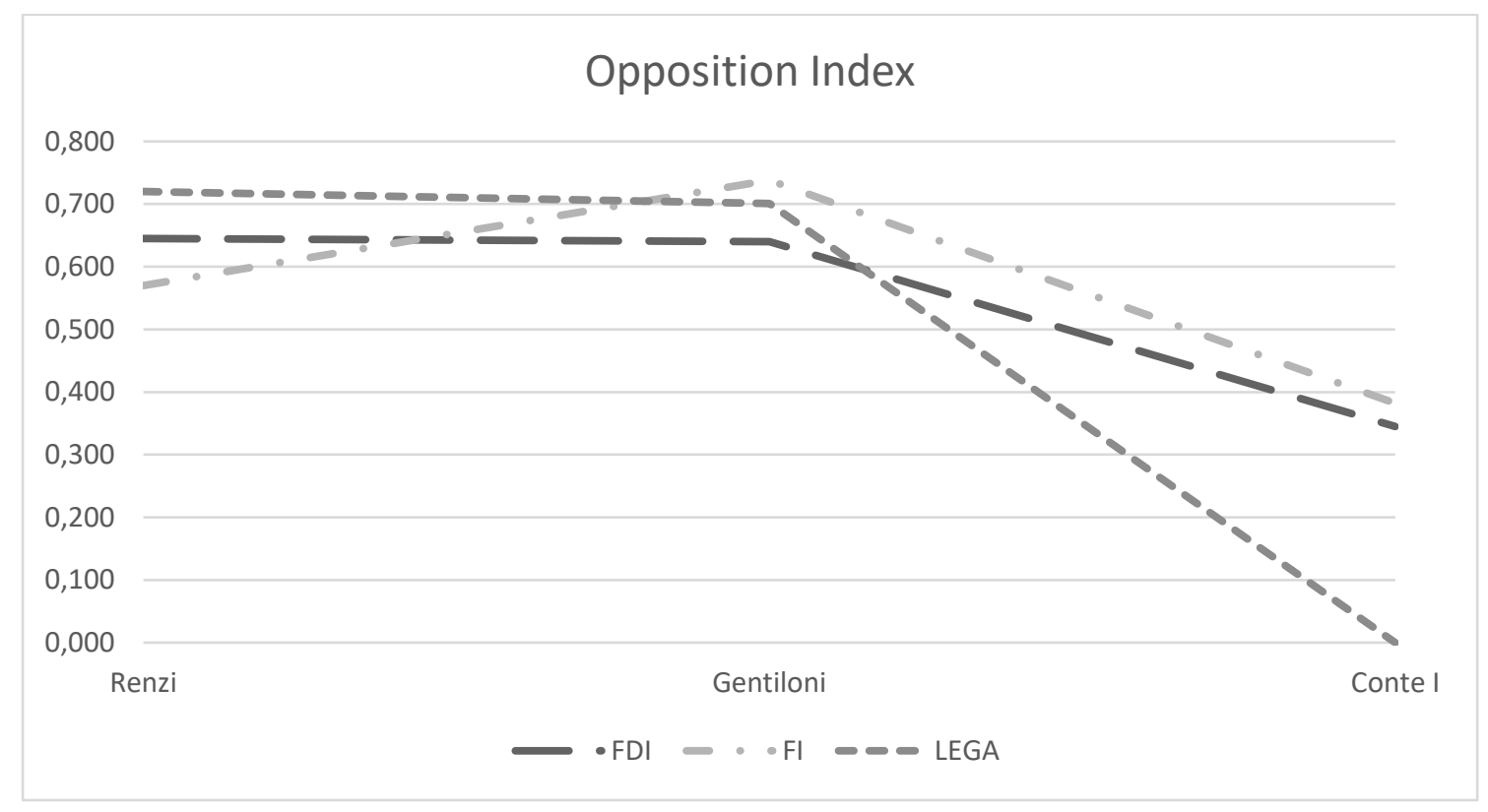

The data presented in Table 3 are rather interesting. In the first place, $\mathrm{Fl}$ and Fdl have opposition index scores in the case of the yellow-green government $(0.382 \text { and } 0.345)^{7}$ lower than the ones for the other opposition parties, i.e. Liberi e Uguali (Free and Equal) (0.500) and the PD (0.576), suggesting, thereby, that their opposition to the first Conte government was not especially intransigent when compared to that of other opposition groups. But what appears especially noteworthy is that the average scores for both FI and Fdl are considerably lower during the first Conte

\footnotetext{
${ }^{7}$ In this case, the index is calculated without taking account of votes to ratify international treaties, which are normally extremely consensual and therefore somewhat misleading (though Table 3 reports, in parentheses, the figures derived where they are included).
} 
government than they are during the Renzi and Gentiloni governments, declining from 0.570/0.738 and $0.645 / 0.640$, to 0.382 and 0.345 . This suggests a significant reduction in the level of conflict.

TABLE 3 Index of opposition for the parliamentary groups, by government, excluding the ratification of international treaties (treaty ratifications included in the figures shown in parentheses)

\begin{tabular}{c|ccc}
\multicolumn{1}{c}{ Party } & Renzi & Gentiloni & Conte I \\
\hline \hline \multirow{2}{*}{ Fdl } & 0.645 & 0.640 & 0.345 \\
& $(0.342)$ & $(0.325)$ & $(0.192)$ \\
FI & 0.570 & 0.738 & 0.382 \\
& $(0.282)$ & $(0.361)$ & $(0.205)$ \\
Lega & 0.720 & 0.701 & 0.000 \\
& $(0.395)$ & $(0.346)$ & $(0.000)$ \\
LEU/SEL & 0.692 & 0.572 & 0.500 \\
& $(0.443)$ & $(0.405)$ & $(0.307)$ \\
M5s & 0.771 & 0.576 & 0.000 \\
& $(0.528)$ & $(0.469)$ & $(0.000)$ \\
MISTO & 0.187 & 0.257 & 0.312 \\
& $(0.117)$ & $(0.153)$ & $(0.175)$ \\
PD & 0.001 & 0.000 & 0.576 \\
& $(0.001)$ & $(0.000)$ & $(0.312)$ \\
\hline \multirow{2}{*}{ Total Votes } & 100 & 26 & 35 \\
& $(205)$ & $(51)$ & $(63)$ \\
\end{tabular}

Naturally, the factors influencing the voting behaviour of parliamentarians in general, as well as of opposition parliamentarians and groups in particular, are multiple. They include the preferences of the individual actors involved - both policy preferences and perceptions of the significance of the issues under discussion - and the characteristics of the laws approved - including their greater or lesser programmatic relevance, and their complexity in terms of scope and objectives (De Giorgi and Marangoni, 2015). However, in this article our aim is, rather, to establish whether the relationships between the parties of the centre right changed at national level after they found themselves on opposite sides of the government-opposition divide. Based on the results of our analysis, the answer would appear to be negative. Outside Parliament, in front of the television cameras (and on social media) the three parties were engaged in a rhetorical battle during the first Conte government. However much this may have been the case, inside Parliament they do not seem to have been any more distant than they were when they found themselves all on the same side, in opposition to the Renzi and Gentiloni governments. The voting behaviour of Fl and Fdl does not appear to have become more antagonistic, rather the contrary, and the level of cooperation between members of the various centre-right groups seems to have remained more or less unchanged. 


\section{Conclusions}

At the beginning of 2019 , the parties of the centre right found themselves in two very different situations according to the context in question. At the regional level, two important victories (Abruzzo and Sardinia) were obtained by deploying the traditional coalition formula, and these were followed by others which, as we have seen, allowed the centre right to overtake the centre left in terms of the number of regions it controlled. At the national/parliamentary level, on the other hand, the historic allies were divided between government and opposition, with the League allied with the M5s in supporting the yellow-green executive. This unprecedented situation, in which the parties found themselves 'divided but not by much', led us to ask how successful the parties were in reconciling their roles as adversaries and allies in the two contexts. We thus proceeded to explore how, in 2019, the elections at regional level unfolded - elections which revealed that the coalition was alive and winning - and how the parties conducted themselves in Parliament in the new set of circumstances.

In the regional context, we have seen that Salvini's League has grown and in so doing confirmed that it is now the dominant party on the centre right - even though this has not been translated into a dominant role within the coalition given the expressions of bad feeling on the part of Berlusconi and his most faithful FI followers. In any case, the perspective shared by all three parties has continued to be the strategic one that they must remain united in order to win.

In the parliamentary arena, we have used, as indicators, co-sponsorship by the other centreright parties of bills presented by one of them, and their voting behaviour in relation to government bills. Doing so, we have been able to observe two different dynamics at work. On the one hand, the degree of cooperation between the three allies remained unchanged when compared with the previous years when all three found themselves sitting among the ranks of the opposition. On the other hand, the level of opposition on the part of $\mathrm{Fl}$ and $\mathrm{Fdl}$, measured by votes against government bills has declined since the Renzi and Gentiloni governments were in office. It appears, in short, that the fact of having considerable experience of governing together, and several coalitions still in office at regional level, in some way influenced the behaviour of FI, Fdl and the League in Parliament, ensuring that it remained cooperative and, in the case of $\mathrm{Fl}$ and Fdl, less antagonistic to the first Conte government. 


\section{References}

Albertazzi, D. (2013) Amici fragili: the alliance between the Lega Nord and the Popolo della Libertà as seen by their representatives and members, Modern Italy, 18(1), 1-18.

Albertazzi, D. and McDonnell, D. (2005) The Lega Nord in the Second Berlusconi Government: In a League of its Own, West European Politics, 28: 952-972.

Albertazzi, D. and McDonnell, D. (2010) The Lega Nord Back in Government, West European Politics, 33(6), 1318-1340.

Biorcio, R. and Vitale, T. (2014) Culture, Values and Social Basis of Northern Italian Centrifugal Regionalism. A Contextual Political Analysis of the Lega Nord. Contemporary Centrifugal Regionalism: Comparing Flanders and Northern Italy, Royal Flemish Academy of Belgium for Science and the Arts Press, 171-199.

Cento Bull, A., and Gilbert, M. (2001) Lega Nord and the Northern Question in Italian Politics, London, Palgrave MacMillan.

Chiaramonte, A., Emanuele, V., Maggini, N. and Paparo, A. (2018) Populist Success in a Hung Parliament: The 2018 General Election in Italy, South European Society and Politics, Advanced online publication, DOI: 10.1080/13608746.2018.1506513.

De Giorgi, E. (2010) Gli equilibri della coalizione di governo, in M. Giuliani e E. Jones (a cura di), Politica in Italia - Edizione 2010, Bologna, II Mulino.

De Giorgi, E. and Marangoni, F. (2015) Government laws and the opposition parties' behaviour in parliament, Acta Politica, 50.

De Giorgi, E. and Tronconi, F. (2018) Il centro-destra in cerca di unità e il riemergere della destra neofascista, in C. Forestiere e F. Tronconi (a cura di), Politica in Italia - Edizione 2018, Bologna, II Mulino.

Emanuele, V. and Maggini, N. [2017], Le elezioni amministrative di giugno, in A. Chiaramonte e A. Wilson (a cura di) Politica in Italia. I fatti dell'anno e le interpretazioni. Edizione 2017, Bologna, il Mulino, 103-122.

Emanuele, V. and Paparo, A. [2017], II centrodestra avanza, il Pd arretra: è pareggio. I numeri finali delle comunali, in La rinascita del centrodestra? Le elezioni comunali del 2017. Roma, CISE, 191199.

Huysseune, M. (2010) A Eurosceptic Vision in a Europhile Country, Modern Italy, 15(1): 63-75.

Passarelli, G. (2013) Extreme right parties in Western Europe: the case of the Italian Northern League, Journal of Modern Italian Studies, 18(1), 53-71. 
Tronconi, F. (2015) Bye-Bye Bipolarism: The 2015 Regional Elections and the New Shape of Regional Party Systems in Italy, South European Society and Politics, 20(4), 553-571.

Vampa, D. [2017], La Lega Nord di Matteo Salvini: fra stasi e nuove opportunità, in Politica in Italia. I fatti dell'anno e le interpretazioni. Edizione 2017, a cura di A. Chiaramonte e A. Wilson, Bologna, il Mulino, pp. 41-59. 